\title{
Medicinal Value of Apricot: A Review
}

\author{
S. GUPTA*, M. CHHAJED ${ }^{1}$, S. ARORA, GURJEET THAKUR AND RENU GUPTA²
}

Department of Pharmacology, Chitkara College of Pharmacy, Chitkara University, Chandigarh-140 401, ${ }^{1}$ Department of Pharmaceutical Chemistry, Indore Institute of Pharmacy, Rau-Pithampur Road, Rau, Indore-453 331, ${ }^{2}$ Dr. Batra's Homeopathic Clinic, M. G. Road, Indore-452 001, India

Gupta, et al: : Apricot a medicinal plant

\begin{abstract}
Herbs are one of the most important sources of medicines for humans for confronting diseases and disorders. Even after several developments in the field of allopathic system of medicine, untoward reactions could not be prevented from being an integral part of modern medicines. Plants are one of the major sources of drug discovery in modern as well as traditional system of medicines worldwide. More than $70 \%$ of marketed drugs are either natural or semisynthetic materials derived from plants. Most literature on complementary alternative medicine worldwide either report the structure of phytoconstituents present in medicinal plants or demonstrate a mechanistic basis for the pharmacological activities possessed by them. Medicinal and therapeutic impact of apricot has not been explored so far. In this review, an attempt has been made highlight the medicinal impact of apricot and its kernel for the treatment of alimentary disorders by summarizing published literature reports till date. Apricot exhibited diversified effects on liver regeneration to myocardial ischemia reperfusion.
\end{abstract}

Key words: Apricot, complementary alternate medicine

Complementary alternative medicine (CAM) is the term for medicinal products and practices that are not a part of standard medicalcare. CAM included practices such as massage, acupuncture, tai chi, consumption of green tea and many more. CAM utilizes diverse classes of natural products, which required to be characterized very crucially and frequently. One of the several drug discovery approaches include isolation of phytoconstituents along with the elucidation of structure, physicochemical properties along with their biological actions and the biochemical, cellular or molecular mechanisms. Natural products are potential tools for the development of therapeutic agents for treating disease and disorders. Research has pointed out that consumption of fruit that contain carbohydrate, fat, proteins, vitamins, minerals, essential micronutrients and essential fatty acids was useful to achieve healthy body functions to perform the physical and mental tasks. Therefore, nutritionists have included fruits on second step of the food pyramid, and highly recommend fruit consumption $^{[1]}$.

A number of researchers reported the benefits of consumption of different fruits that included apricot and its kernel. Additionally a number of studies elaborated the pharmacological and biological effects

${ }^{*}$ Address for correspondence E-mail: saurabhgupta80@gmail.com of apricot. In the current review, a compiled summary of information out of published studies has been presented of which the foremost focus was on apricot and its kernel only. Apricot is also known as stone fruit, belonging to genus Prunus. Usually, an apricot tree is Prunus armeniaca, but some similar species like $P$. brigantina, $P$. mandshurica, $P$. mume and $P$. sibirica are also known as apricots ${ }^{[2-4]}$.

\section{Description and cultivation:}

Apricot is a small tree, 7-10 m tall with a trunk up to $40 \mathrm{~cm}$ in diameter and a dense spreading canopy. The leaves are ovate, 5-9 $\mathrm{cm}$ long and 4-8 $\mathrm{cm}$ wide, with a rounded base, a pointed tip and a finely serrated margin. The flowers are $2-4.5 \mathrm{~cm}$ in diameter, with five white to pinkish petals; they are produced singly or in pairs in early spring before the leaves. The fruit is a drupe similar to a small peach, $1.5-2.5 \mathrm{~cm}$ diameter, from yellow to orange, often tinged red on the side

This is an open access article distributed under the terms of the Creative Commons Attribution-NonCommercial-ShareAlike 3.0 License, which allows others to remix, tweak, and build upon the work non-commercially, as long as the author is credited and the new creations are licensed under the identical terms

Accepted 07 July 2018

Revised 02 June 2017

Received 20 January 2017

Indian J Pharm Sci 2018;80(5):790-794 
most exposed to the sun; its surface can be smooth or velvety with very short hairs. The flesh is usually firm and not very juicy. Its taste can range from sweet to tart. The single seed is enclosed in a hard, stony shell, often called a 'stone', with a grainy, smooth texture except for three ridges running down one side. The apricot is native to continental climate region with cold winters. A dry climate is good for fruit maturation. A limiting factor in apricot cultivation is spring frosts as these plants tend to flower in early spring (early March in Western Europe), meaning spring frost could kill the flowers. Furthermore, the trees are sensitive to temperature changes during the winter season. Apricot cultivars are most often grafted onto plum or peach rootstocks.

\section{Pharmacological activity profile:}

A variety of pharmacological effects of apricot and its kernel have been reported which included antiparasitic, anticancer, antiaging, antiatherosclerating, antianginal, cardioprotective, hepatoprotective, renoprotective and antioxidant (especially $\beta$-carotene). It also has been reported that apricot fruit is rich in good minerals especially $\mathrm{K}, \mathrm{Fe}, \mathrm{Mg}$ and $\mathrm{P}$. Apricot is also a very good source of vitamin A, C and E and fibre. Studies also reported apricot to exhibit sedative, antispasmolytic, anticestodal, antimicrobial, antimutagenic, antitussive, antiinflammatory, antinociceptive, enzyme inhibitory and tonic effects ${ }^{[3-9]}$. Miguel et al. made a special mention that flavonoids have beneficial consequences in several cardiovascular and cerebrovascular diseases and also in some forms of cancer, Parkinson's and Alzheimer's diseases. In the aforementioned study, these authors also reported that flavonoids such as quercetin-3-rutinoside, quercetin-3-galactoside and quercetin-3-glucoside are the chief constituents in $\operatorname{apricots}^{[10]}$.

Cultivation and marketing statistics of apricot in Malatya province were reported by Parlakpinar et al. ${ }^{[1]}$. Parlakpinar et al. also reported the cardioprotective activity of apricot in rats and attributed that activity to the presence of antioxidant phenolic compounds ${ }^{[11]}$. Chemical constituents such as, phenol, minerals, vitamins, lipids and carbohydrate content of apricot might vary with the altitude, apricot species, soil structure and fertilizer use $\mathrm{e}^{[5]}$. The apricot varieties, namely Zerdali, Cataloglu, Hacihaliloglu, Hasanbey, Kabaasi, Cekirge, Ethembey (Alyanak and Tokaloglumore west Anatolia) and Hacikız that are widely cultivated in Malatya ${ }^{[12-17]}$.

September-October 2018

Indian Journal of Pharmaceutical Sciences
Gezer et al. reported crude oil, dry matter, crude protein, crude fibre and mineral contents as well as some physical properties such as mass, length, width, thickness, sphericity, volume, bulk density, kernel density, porosity and terminal velocity of kernels of five apricot species, which were cultivar in Malatya. These authors reported that all kernels contained high amounts of $\mathrm{Ca}, \mathrm{K}, \mathrm{Na}$ and $\mathrm{P}$, which was indicative that apricot kernels useful as nutritive and an oil source $^{[16]}$. It was also reported that vitamins $\mathrm{A}, \mathrm{C}$ and $\mathrm{E}$ and malondialdehyde (MDA) contents of apricot were better preserved on microwave drying relative to infrared drying ${ }^{[4]}$.

It was reported that a significant amount of polyphenol oxidase enzyme was extracted from the Igdir apricot ${ }^{[18]}$. Haciseferogullari et al. ${ }^{[12]}$ investigated some nutritional aspects of six apricot species that included the dry matter, ash, crude oil, crude protein, crude fibre, $\mathrm{pH}$, acidity, water-soluble extract/alcohol-soluble extract, and mineral $(\mathrm{K}, \mathrm{P}, \mathrm{Ca}, \mathrm{Na}$ and $\mathrm{Mg}$ ) contents of completely maturated fruits. They underlined that such information would be useful for the evaluation of the nutritional status of apricot fruit ${ }^{[12]}$. It was reported that, dry matter and carbohydrates such as sucrose, glucose, fructose and sorbitol content of Malatya apricot varieties were considerably higher than the other varieties and found to be a good source of phenolic compounds. It has been also reported that maleic acid is the predominant organic acid in all Malatya apricot varieties. The authors also indicated that the potassium content of Malatya apricots was significantly high and these apricots were an important source of $\mathrm{Mg}$, $\mathrm{Zn}$ and Se, and other functional food components with high nutritional value ${ }^{[14]}$. In the nine apricot varieties studied, the total oil content of apricot kernels ranged from 40.23 to $53.19 \%$. Oleic acid contributed $70.83 \%$ to the total fatty acids, followed by linoleic acid $(21.96 \%)$, palmitic acid $(4.92 \%)$ and stearic acid $(1.21 \%)$ as reported by Turan et al. ${ }^{[13]}$. It was reported in another study that the seed oil was a rich source of $\mathrm{P}, \mathrm{Ca}, \mathrm{Mg}, \mathrm{Fe}$ and $\mathrm{Cu}$, and contained oleic acid (73.58\%), linoleic acid (19.26\%), palmitic acid $(3.31 \%)$, myristic acid (1.18 \%) and stearic acid $(2.68 \%)^{[19]}$. It has also been reported that apricot kernel oil caused improvement in liver antioxidant status of rats in comparison to sunflower oil, a commonly consumed vegetable oil ${ }^{[20]}$. In another study, apricot kernel extract was shown to ameliorate colon inflammation and ulcers induced by trinitrobenzene sulfonic acid, an experimental model of colitis in rats. 
Different active components and mechanisms might be involved in these beneficial effects, thus more detailed studies were needed for more accurate clarification ${ }^{[9]}$.

Kutlu and coworkers reported the hepatoprotective effect exhibited by the leaf extract against paracetamolinduced liver toxicity in rats, which was further confirmed in histopathological examinations ${ }^{[21]}$. Ugur et al. isolated the following flavonoids from apricot leaves, chlorogenic acid, rutin, catechin and naringin. According to the growth season while rutin and catechin (in some apricot species chlorogenic acid) levels were shown an increase, but in some other apricot species chlorogenic acid and naringin levels were shown exponentially to decrease ${ }^{[17]}$.

Vardi et al. reported that apricot and/or $\beta$-carotene treatment protected against the impairment of oxidative stress and ameliorated methotrexate-induced intestinal damage ${ }^{[22]}$. The effects of sun dried organic apricot (SDOA) supplementation to rat chow consumption on some serum mineral levels at four different rates like $1,2,5$ and $10 \%$ and three different periods on both genders of rats were reported by Yilmaz et al. ${ }^{[23]}$.

According to some reports, there was an augmentation in the $\mathrm{K}^{+}$levels in the serum while at the same time $\mathrm{Ca}$, $\mathrm{Mg}$ and $\mathrm{P}$ levels declined with no difference in $\mathrm{Na}^{+}$and Fe levels in rats fed with high dose of SDOA. Chemical composition of SDOA indicated that it is poorer in mineral contents except $\mathrm{K}$ compared to rat chow. The most suitable supplementation is found to be $1 \%$ SDOA for $30 \mathrm{~d}$. In addition, a marked difference was noticed between P levels in the male and Fe levels in female rats $^{[23]}$. It was further reported that consumption of $1 \%$ SDOA for $120 \mathrm{~d}$ SDOA showed beneficial effects in rats of either sex, especially on red blood cells, haemoglobin and hematocrit. The aforementioned reports revealed that comsumption of SDOA might be beneficial for treatment, prevention and/or elimination of the risk of development of anaemias in humans ${ }^{[24]}$. In some other studies the effects of SDOA supplementation to rat chow on serum proteins and liver enzymes was examined. SDOA content in diet inversely influenced the levels of alkaline phosphatase, acetyl transferase and total protein (TP) in rats. Considering periods of feeding, a significant role was observed on albumin, alkaline transferase and TP levels in genders. The amount of $1 \%$ exerted beneficial effects on parameters in both sexes. However, there were no significant interaction between the amounts and the periods for which the diet was supplemented ${ }^{[25]}$. Supplementation of food with
2.5 and $5 \%$ SDOA in male rats and $10 \%$ SDOA in female rats exerted significant positive effect in their daily food intake ${ }^{[26]}$. In 2013, Yilmaz and co-workers reported, $5 \%$ SDOA supplementation over $21 \mathrm{~d}$ period had beneficial effects on the regenerative capacity of remnant liver after $70 \%$ partial hepatectomy $(\mathrm{PH})$ which were similar to $\mathrm{Ki}-67$ findings ${ }^{[27]}$. In a similar fashion Yormaz and coworkers in another study reported that, before 7 and after $10 \mathrm{~d}$ of $\mathrm{PH}$ silymarin administration exhibited beneficial effect along with SDOA consumption, on remnant liver regeneration of rats $^{[28]}$.

In 2015, Yilmaz et al. reported the effects of SDOA supplementation on the activity of oxidative stress enzymes such as superoxide dismutase, MDA, catalase, glutathione and glutathione $\mathrm{S}$ transferase of large intestines at three different periods in rats and also revealed that at least $1 \%$ SDOA consumption for $30 \mathrm{~d}$ has beneficial effects on rats of either $\operatorname{sex}^{[29]}$. Additionally, hepatoprotective effects were reported against acute acetaminophen overdose-induced liver histopathology in rats ${ }^{[30]}$ and ketamine inducedhepatotoxicity in rats ${ }^{[31]}$. Ozturk et al. reported the beneficial effects of long-term apricot feeding on $\mathrm{CCl}_{4}$ induced liver steatosis and damage in rats and attributed the beneficial effects to the high free radical scavenging capacity. As a natural food, apricot appeared to have beneficial effects on non-alcoholic hepatic steatosis ${ }^{[32]}$.

Ugras and coworkers reported that after low dose irradiation on testis tissue in rats, apricot-rich diet containing $20 \%$ supplementation significantly ameliorated the oxidative status, due mainly to its natural antioxidant activity. These prominent protective effects were observed when the diet was maintained throughout the course of time but initiated after exposure ${ }^{[33]}$. In a similar manner, Kurus et al. reported that apricot-rich diet showed a significant preventive role on histopathological changes caused by alcohol in rat testis and also exerted an encouraging effect in the treatment of renal diseases ${ }^{[34]}$. Efficient combination ratios of rat chow and apricot have been reported by Ugras et al. ${ }^{[33]}$. Yurt and Celik investigated the protective effects of sulphited dried apricot and its kernel on some detoxification enzymes during exposure of rats to alcohol and concluded that apricot has a hepatoprotective effect probably by promoting the antioxidative defence systems ${ }^{[35]}$. Apricot kernel appeared to be an important natural antioxidant source like tocopherols and phenolic compounds ${ }^{[36]}$. 
The vitamins $\mathrm{A}, \mathrm{C}$, and $\mathrm{E}, \beta$-carotene and selenium contents of apricot showed some differentiation according to the fresh and sulphur-dried production, post-harvest processing, altitude of region, cultivar or wild type and also among cultivars as reported by Munzuroglu et al. ${ }^{[37]}$. Ruiz et al. determined the differences among apricot varieties and their flesh colour and phenolic compound as procyanidins and anthocyanins by HPLC. They reported that, the total phenolic content ranged between 32.6 and $160.0 \mathrm{mg} / 100 \mathrm{~g}$ of edible tissue, and further revealed that there is no correlation between the flesh colour and the phenolic content of the different cultivars ${ }^{[38]}$. On the other hand, the same authors emphasised in their report that apricot colour has a large influence not only on consumer perception about quality but also on nutritional appreciation for their vitamin A content ${ }^{[39]}$.

Yiğit et al. reported that, the most effective antibacterial activity was observed in the methanol and water extracts of bitter kernels and in the methanol extract of sweet kernels of apricot against the Gram-positive bacteria ${ }^{[4]}$. Furthemore, the methanol extract of the bitter kernels had very potent activity against the Gram-negative bacteria. Significant antifungal activity against candida species was also observed with the methanol extract of bitter apricot kernels, whereas significantly high antioxidant activity was recorded, especially in sweet kernel extracts ${ }^{[40]}$.

The Japanese apricot (Prunusmume) preparations prevented colonization of $H$. pylori in the gastric mucosa, hence prevent gastritis, but by unknown inhibition mechanism as reported by Miyazawa et $a l .{ }^{[3]}$. Jaya and Lamba reported that most effective antibacterial activity was observed in the ethanol extract of fruits against Staphylococcus aureus and Bacillus subtilis. Additionally, the ethanol extract has significant activity against Proteus vulgaris, Escherichia coli and also against Candida albicans. The ethanol extract showed more significant antimicrobial activity as compared to aqueous extract ${ }^{[41]}$. In the aforementioned study it has also been reported that out of the antitubercular effect exerted by the aqueous and ethanol extracts of fruits of $P$. armeniaca (L.) evaluated on Mycobactarium tuberculosis, the effect of the ethanol extract is more pronounced ${ }^{[42]}$. In another study, it was reported that the extract showed good antimicrobial activity against Gram-positive bacteria. Hence it could be conclude that dry apricot is a good source of health promoting constituents, used for therapeutic purpose ${ }^{[8]}$.

\section{Nutritional value:}

In a 100 g quantity, raw apricots appear to supply 48 calories composed of $11 \%$ carbohydrates, $1 \%$ protein, less than $1 \%$ fat and $86 \%$ water. Raw apricots are a moderate source of vitamin A and vitamin C (12\% of the daily value each). When apricots are dried, the relative concentration of nutrients is increased, with vitamin $\mathrm{A}$, vitamin $\mathrm{E}$, potassium and iron having daily values above $25 \%$.

Present review captured the recent publications by different researchers, which reflected the effects of active constituents of apricot against different disorders. Apricot appeared to have enormous potential not only to prevent diseases but also to cure some of them. There is an unmet need to exploit maximum potential in the field of medicinal plants for novel and fruitful applications, since herbal drugs are a holistic gift of the nature. Daily consumption of apricot should not be neglected, whereas over consumption of the fruit to be avoided since it could cause alterations in the neurotransmitter activity by acting on calcium ions. As discussed above there are several species available in the market and attention is a must before consumption of the apricot since it is not very clear which has the maximum nutritive value. Hence after exhaustive literature review, it could be concluded that apricot is one of the rare fruits that could serve as a useful nutritional and therapeutic agent against certain disease and disorder conditions but with certain limitations.

\section{Conflicts of interest:}

There are no conflicts of interest among the authors.

\section{REFERENCES}

1. Georgiou NA, Garssen J, Witkamp RF. Pharma nutrition interface: The gap is narrowing. Eur J Pharmacol 2011;651(13):1-8.

2. Kahlon TS, Smith GE. In vitro binding of bile acids by bananas, peaches, pineapple, grapes, pears, apricots and nectarines. Food Chem 2007;101:1046-51.

3. Miyazawa M, Utsunomiya H, Inada K, Yamada T, Okuno Y, Tanaka $\mathrm{H}$, et al. Inhibition of Helicobacter pylori motility by $(+)$-syringaresinol from unripe Japanese apricot. Biol Pharm Bull 2006;29(1):172-3.

4. Yiğit D, Yiğit N, Mavi A. Antioxidant and antimicrobial activities of bitter and sweet apricot (Prunus armeniaca L.) kernels. Braz J Med Biol Res 2009;42(4):346-52.

5. Yilmaz I. Carotenoids. J Turgut Ozal Med Cent 2010;17:223-31

6. Erdogan-Orhan I, Kartal M. Insights into research on phytochemistry and biological activities of Prunus armeniaca L. (apricot). Food Res Int 2011;44:1238-343. 
7. Raj V, Jain A, Chaudhary J. Prunus armeniaca (Apricot): An Overview. J Pharm Res 2012;8:3964-6.

8. Sharma S, Satpathy G, Gupta RK. Nutritional, phytochemical, antioxidant and antimicrobial activity of Prunus armenicus. J Pharmacogn Phytochem 2014;3:23-8.

9. Minaiyan M, Ghannadi A, Asadi M, Etemad M, Mahzouni P. Anti-inflammatory effect of Prunus armeniaca L. (Apricot) extracts ameliorates TNBS-induced ulcerative colitis in rats. Res Pharm Sci 2014;4:225-31.

10. Miguel G, Dandlen S, Neves A, Antunes D. Flavonoids content of different apricot (Prunus armeniaca L.) cultivars. $4^{\text {th }}$ IASME/WSEAS International Conference on Energy, Environment, Ecosystems and Sustainable Development (EEESD'08). Algarve/Portugal: WSEAS- World Scientific and Engineering Academy and Society; 2008.

11. Parlakpinar H, Olmez E, Acet A, Ozturk F, Tasdemir S, Ates $\mathrm{B}$, et al. Beneficial effects of apricot-feeding on myocardial ischemia-reperfusion injury in rats. Food Chem Toxicol 2009; 47:802-8.

12. Haciseferogullari H, Gezer I, Ozcan MM, Asma BM. Postharvest chemical and physical-mechanical properties of some apricot varieties cultivated in Turkey. J Food Eng 2007;79:364-73.

13. Turan S, Topcu A, Karabulut I, Vural H, Hayaloglu AA. Fatty Acid, Triacylglycerol, Phytosterol, and Tocopherol Variations in kernel oil of Malatya apricots from Turkey. J Agric Food Chem 2007;55:10787-94.

14. Akin EB, Karabulut I, Topcu A. Some compositional properties of main Malatya apricot (Prunus armeniaca L.) varieties. Food Chem 2008;107:939-48.

15. Ercisli S, Agar G, Yıldırım N, Esitken A, Orhan E. Identification of apricot cultivars in Turkey (Prunus armeniaca L.) using RAPD markers. Rom Biotechnol Lett 2009;14:4582-8.

16. Gezer I, Haciseferogullari H, Ozcan MM, Arslan D, Asma BM, Unver A. Physico-chemical properties of apricot (Prunus armeniaca 1.) kernels. South Western J Hortic Biol Env 2011;2:1:1-13.

17. UgurY, Erdogan S, Yilmaz I, Basgel S. Variation of quantitative composition of phenolic compounds in the apricot (Prunus armeniaca L.) leaves during the growth seasons. J Nat Prod Plant Resour 2018;8(1):33-9.

18. Sehgal J, Siddheswaran P, Kumar KLS, Karthiyayini T. Antitubercular activity of fruits of Prunus armeniaca (L.). Int J Pharm Biol Sci 2010;2:1-4.

19. Demir H, Cimen C, Celikezen FC. Purification and characterization of polyphenol oxidase enzyme from Igdir apricot (Prunus armeniaca L.). Bitlis Eren Univ J Sci Technol 2012;2:22-6.

20. Bachheti RK, Rai I, Joshi A, Rana V. Physico-chemical study of seed oil of Prunus armeniaca L. grown in Garhwal region (India) and its comparison with some conventional food oils. Int Food Res J 2012;19(2):577-81.

21. Kutlu T, Durmaz G, Ates B, Erdogan A. Protective effect of dietary apricot kernel oil supplementation on cholesterol level and antioxidant status of liver in hypercholesteremic rats. J Food Agric Environ 2009;3(4):61-5.

22. Vardi N, Parlakpinar H, Ozturk F, Ates B, Gul M, Cetin A, et al. Potent protective effect of apricot and $\beta$-carotene on methotrexate-induced intestinal oxidative damage in rats. Food ChemToxicol 2008;46:3015-22.

23. Yilmaz I, Temel I, Gursoy S, Dogan Z, Turkoz Y. Effects of sun dried organic apricot on some serum mineral levels in rats. Int Res J Pharm 2012;03:62-7.
24. Yilmaz I. Effects of sun dried organic apricot on some hematological parameters in rats. J Pharm Res 2012;3:18-22.

25. Yilmaz I, Temel I, Gursoy S, Dogan Z. The effects of apricot on serum proteins and liver enzymes in rats. J Food Nutr Res 2013;2:101-06

26. Yilmaz I, Dogan Z, Soysal H. The effects of dried apricot supplementation on daily food intake in rats. Turk J Pharma Sci 2013;1:137-44.

27. Yilmaz I, Karaman A, Vardi N, Cetin A, Erdemli E. Effects of organic apricot on liver regeneration after partial hepatectomy in rats. Transplant Proc 2013;2455-60.

28. Yormaz S, Bulbuloglu E, Kurutas EB, Ciralik H, Yuzbasioglu MF, Yildiz H, et al. The comparison of the effects of hepatic regeneration after partial hepatectomy, Silybum marinaum, propofol, $N$-acetylcysteine and vitamin E on liver. Bratisl Lek Listy 2012;3:145-51.

29. Yilmaz I, Hatipoglu HS, Taslidere E, Karaaslan M. Comparing the regenerative effects of Silymarin and Apricot on liver regeneration after partial hepatectomy in rats. Biomed Res 2018;29(7):1465-73.

30. Yilmaz I, Dogan Z, Erdemli E, Gursoy S, Bag HG. The effects of apricot on large intestine oxidative stress enzymes in rats. $\mathrm{J}$ Cytol Histol 2015;6:2.

31. Yilmaz I, Cetin A, Bilgiç Y. Hepatoprotective effects of apricot against acetaminophen-induced acute hepatotoxicity in rats. Am J Pharmacol Sci 2015;2:44-8.

32. Ozturk F, Gul M, Ates B, Ozturk IC, Cetin A, Vardi N, et al. Protective effect of apricot (Prunus armeniaca L.) on hepatic steatosis and damage induced by carbon tetrachloride in Wistar rats. Br J Nutr 2009;102:1767-75.

33. Ugras MY, Kurus M, Ates B, Soylemez H, Otlu A, Yilmaz I. Prunus armeniaca L (apricot) protects rat testes from detrimental effects of low-dose x-rays. Nutr Res 2010;30:200-8.

34. Kurus L, Ugras M, Ates B, Otlu A. Apricot ameliorates alcohol induced testicular damage in rat model. Food Chem Toxicol 2009; 10:2666-72.

35. Yurt B, Celik I. Hepatoprotective effect and antioxidant role of sun, sulphited-dried apricot (Prunus armeniaca L.) and its kernel against ethanol-induced oxidative stress in rats. Food Chem Toxicol 2011;49:508-13.

36. Durmaz G, Alpaslan M. Antioxidant properties of roasted apricot (Prunus armeniaca L.) kernel. Food Chem 2007;100:1177-81.

37. Munzuroglu O, Karatas F, Geckil H. The vitamin and selenium contents of apricot fruit of different varieties cultivated in different geographical regions. Food Chem 2003;2:205-12.

38. Ruiz D, Egea J, Gil MI, Tomas-Barberan FA. Characterization and quantitation of phenolic compounds in new apricot (Prunus armeniaca L.) varieties. J Agric Food Chem 2005;53:9544-52.

39. Ruiz D, Egea J, Tomas-Barberan FA, Gil MI. Carotenoids from new apricot (Prunus armeniaca L.) varieties and their relationship with flesh and skin color. J Agric Food Chem 2005;53:6368-74.

40. Karataş F, Kamisli F. Variations of vitamins (A, C and E) and MDA in apricots dried in IR and microwave. J Food Process Eng 2007;78:662-8.

41. Jaya S, Lamba HS. Antimicrobial activity of fruits of Prunus armeniaca (L.). J Drug Deliv Ther 2012;4:163-6.

42. Raj V, Mishra AK, Mishra A, Ali NK. Hepatoprotective effect of Prunus armeniaca L. (Apricot) leaf extracts on Paracetamol induced liver damage in Wistar rats. Pharm J 2016;2:154-8. 